\title{
Immunohistochemical Study to Evaluate the Prognostic Significance of Four Biomolecular Markers in Radiotherapy of Nasopharyngeal Carcinoma
}

\author{
Yeon-Joo Kim, M.D.*, Seung Hee Lee, M.S.*, ${ }^{* \S}$, Hong-Gyun Wu, M.D., Ph.D.*, ${ }^{*}$, \\ Heounjeong Go, M.D. ${ }^{\dagger}$, and Yoon Kyung Jeon, M.D., Ph.D. ${ }^{\dagger}$ \\ Departments of ${ }^{\star}$ Radiation Oncology, ${ }^{\dagger}$ Pathology, and ${ }^{\dagger}$ Cancer Research Institute, \\ Seoul National University College of Medicine, ${ }^{\S}$ Institute of Radiation Medicine, \\ Medical Research Center, Seoul National University, Seoul, Korea
}

\begin{abstract}
Purpose: We performed an immunohistochemical study with pre-treatment biopsy specimens to evaluate the prognostic significance of four biomolecular markers which can be used as a predictive assay for radiotherapy (RT) treatment of nasopharyngeal carcinoma (NPC).

Materials and Methods: From January 1998 through December 2006, 68 patients were histologically diagnosed as non-metastatic NPC and treated by RT. Only 38 patients had the paraffin block for the immunohistochemical study. Thirty-one patients had undifferentiated carcinoma and 7 patients had squamous cell carcinoma. Thirtytwo patients (84\%) had advanced stage NPC (2002 AJCC Stage III IV). Immunohistochemical staining was performed for Met, COX-2, nm23-H1, and epidermal growth factor receptor (EGFR) expression using routine methods.

Results: The median follow-up time was 30 months (range, 11 to 83 months) for all patients, and 39 months (range, 19 to 83 months) for surviving patients. The 5-year overall survival (OS) rate of the patients with high Met extent $(\geq 50 \%)$ was significantly lower than that of the patients with low Met extent (48\% vs. $84 \%$, $p=0.02$ ). In addition, Met extent was also a significant prognostic factor in multivariate analysis $(p=0.01)$. No correlation was observed between Met extent and $\mathrm{T}$ stage, $\mathrm{N}$ stage, stage group, gender, age, and the response to chemotherapy or RT. Met extent showed moderate correlation with COX-2 expression (Pearson coefficient $0.496, \mathrm{p}<0.01$ ), but COX-2 expression did not affect OS. Neither nm23-H1 or EGFR expression was a prognostic factor for OS in this study.

Conclusion: High Met extent $(\geq 50 \%)$ might be an independent prognostic factor that predicts poor OS in NPC treated with RT.
\end{abstract}

Key Words: Nasopharyngeal carcinoma, Radiotherapy, Prognostic factor, Immunohistochemical staining, Met

\footnotetext{
Submitted December 18, 2009, accepted March 22, 2010

Reprint requests to Hong-Gyun Wu, M.D., Ph.D., Department of Radiation Oncology, Seoul National University College of Medicine, 28 Yongon-dong, Chongno-gu, Seoul 110-744, Korea

Tel: 02)2072-3177, Fax: 02)765-3317

E-mail: wuhg@snu.ac.kr

This work was supported by a grant, No. 04-2008-023, from the Seoul National University Hospital Research Fund, grant No. 2009-0083886 from the Korea Science and Engineering Foundation grant funded by the Korea government, and grant No. 0620270 from the National R\&D Program for Cancer Control, Ministry of Health Family \& Welfare, Korea.
}

\section{Introduction}

Nasopharyngeal carcinoma (NPC) is a relatively common disease in Southeast Asia. In South Korea, the incidence of NPC is 0.7 per 100,000 according to the Korean National Cancer Registry Report 2005. ${ }^{1)}$ Asian NPC is distinct from Western NPC in that more than $90 \%$ of cases are nonkeratinizing and undifferentiated carcinoma (WHO types II and III). ${ }^{2)}$ NPC is sensitive to ionizing radiation and it can be cured with radiotherapy (RT) or concurrent chemoradiotherapy (CCRT). However, the treatment outcomes are variable even 
in same staged patients. In addition to the clinical prognostic factors such as gender, age or stage, biomolecular characteristics of the tumor may affect the treatment outcome. If proper biomolecular markers are identified, we could provide a more tailored therapy for each patient and achieve better treatment outcomes. Epidermal growth factor receptor (EGFR) expression is known as one of the prognostic factors in head and neck squamous cell carcinoma and EGFR inhibitor improves survival rate. ${ }^{3)}$ However, the prognostic value of EGFR is still controversial in NPC. Although there are studies which showed correlation between biomolecular markers and treatment outcomes in NPC, the data is still insufficient to apply to the clinical field. We searched Pubmed (www.pubmed.gov) for biomolecular markers in NPC and found that several markers showed correlation with the clinical outcome. In current study, we evaluated the prognostic value of Met, COX-2, nm23-H1 and EGFR expression in pre-treatment biopsy specimens.

\section{Materials and Methods}

\section{Patients}

From January 1998 to December 2006, 68 patients were histologically diagnosed as non-metastatic NPC and treated with RT. Only 38 patients had the pre-treatment biopsy paraf-

Table 1. Patients Characteristics

\begin{tabular}{llc}
\hline \hline \multicolumn{2}{c}{ Characteristics } & No. of patient $(\%)$ \\
\hline \multirow{2}{*}{ Gender } & Male & $30(79)$ \\
& Female $(\mathrm{yr})$ & $8(21)$ \\
& Median (range) & $48(25 \sim 74)$ \\
& $<50$ & $21(55)$ \\
Histology & $\geq 50$ & $17(45)$ \\
& Squamous cell carcinoma & $7(18)$ \\
T stage & Undifferenciated carcinoma & $31(82)$ \\
& $0 \sim 1$ & $10(26)$ \\
& 2 & $10(26)$ \\
N stage & 3 & $10(26)$ \\
& 4 & $8(21)$ \\
& 0 & $4(11)$ \\
\multirow{5}{*}{ Stage } & 2 & $11(29)$ \\
& 3 & $17(45)$ \\
& I & $6(16)$ \\
& IIB & $1(2)$ \\
& III & $5(13)$ \\
& IVA-IVB & $18(47)$ \\
& & $14(37)$ \\
\hline
\end{tabular}

fin block available for the immunohistochemical study. Patient characteristics are summarized in Table 1. Male was dominant (79\%) similar to other studies. The median age was 48 (range, 25 to 74 years), and thirty-one patients had undifferentiated carcinoma and 7 patients had squamous cell carcinoma. Thirty-two patients (84\%) had advanced stage NPC (2002 AJCC Stage III-IV). The institutional review board approved this study before the review of medical records.

\section{Treatment}

Table 2 describes the treatment details. Thirty-two of 38 patients were treated with induction chemotherapy with two or three cycles of cisplatin based regimen followed by either radiotherapy alone (19 patients) or concurrent chemoradiotherapy with cisplatin (13 patients). Since May 2004, all patients were treated with intensity modulated radiotherapy (IMRT) using integrated boost simultaneously. All patients, except for one, were prescribed more than $82 \mathrm{~Gy}_{10}$ (biologically effective dose, $\alpha / \beta$ ratio=10) to the gross target volume. Posterior nasal cavity, posterior maxillary sinuses,

Table 2. Treatment Characteristics

\begin{tabular}{cr}
\hline \hline Characteristics & No. of patient (\%) \\
\hline Induction chemotherapy & $32(84)$ \\
Yes & $14(37)$ \\
$\mathrm{DFP}^{*} \# 2 \sim 3$ & $14(37)$ \\
$\mathrm{FP}^{\dagger} \# 2 \sim 3$ & $4(10)$ \\
$\mathrm{TP}^{\ddagger} \# 3$ & $19(50)$ \\
Followed by Radiotherapy alone & $13(34)$ \\
Concurrent chemoradiotherapy & $6(16)$ \\
No & $1(3)$ \\
Radiotherapy alone & $5(13)$ \\
Concurrent chemoradiotherapy & $2(5)$ \\
Consolidation chemotherapy & \\
Radiotherapy & $14(37)$ \\
Technique & $2(5)$ \\
2-dimensional & $22(58)$ \\
3-dimensional & $10(26)$ \\
IMRT & $4(10)$ \\
Dose (BED ${ }^{\|}, \alpha / \beta$ ratio=10) & $21(56)$ \\
70.2 Gy (82.8) & $1(3)$ \\
70.0 Gy (84.0) & $2(5)$ \\
67.5 Gy (82.7) & \\
66.6 Gy (78.6) & \\
Incomplete radiotherapy & \\
(64/70 Gy, 63/67.5 Gy) &
\end{tabular}

${ }^{*}$ Docetaxel+5-FU+Cisplatin, ${ }^{\dagger}$ 5-FU+Cisplatin, ${ }^{\dagger}$ Paclitaxel+Cispla-

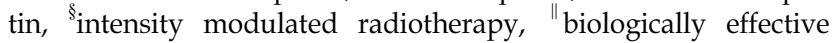
dose. 
pterygoid fossae, parapharyngeal spaces and involved neck node level received about $64 \mathrm{~Gy}_{10}$ and elective neck node level about $52 \mathrm{~Gy}_{10}$. Two patients could not complete radiotherapy due to personal reasons. One received 64 Gy out of 70 Gy and the other 63 Gy out of $67.5 \mathrm{~Gy}$.

\section{Immunohistochemical staining}

Formalin-fixed paraffin-embedded tissue was cut into $4-\mu \mathrm{m}-$ thick sections and mounted on poly-L-lysine-coated slides. The sections were then deparaffinised in xylene and rehydrated in ethanol. The antigen retrieval procedure was performed by immersing the slides in citrate buffer ( $\mathrm{pH}$ 6.0) and then heating the slides in a microwave oven for 15 minutes for Met, Cox-2, and nm23-H1. The sections were incubated at $37^{\circ} \mathrm{C}$ for 10 minutes in $20 \mathrm{ug} / \mathrm{mL}$ proteinase $\mathrm{K}$ enzyme solutions for EGFR and allowed to cool to room temperature for $15 \mathrm{~min}$. Endogenous peroxidase activity was then blocked with methanol containing $3 \% \quad \mathrm{H}_{2} \mathrm{O}_{2}$ for 10 minutes. The sections were treated for $40 \mathrm{~min}$ at room temperature with blocking reagent of Cap- Plus Detection Kit (Zymed, San Francisco, CA, USA), and incubated overnight at $4^{\circ} \mathrm{C}$ with primary antibodies (Met: rabbit polyclonal antibody, dilution 1:200, Santa Cruz; COX-2: mouse monoclonal antibody, dilution 1:500, Cayman; nm23-H1: mouse monoclonal antibody, dilution 1:45, Santa Cruz; EGFR: mouse monoclonal antibody, dilution 1:50, invitrogen). Then the sections were sequentially incubated with secondary antibodies and streptavidin-HRP of Cap-Plus Detection Kit (Zymed) for 30 minutes. All tissues were then exposed to diaminobenzidine as chromogen for $2 \sim 5$ minutes, and hematoxylin as counterstain for 2 minutes. The degree of staining was determined by two independent observers on a $\times 200$ field.

\section{Statistical methods}

The aim of the study was to explore the prognostic value of Met, COX-2, nm23-H1 and EGFR. The primary end points were overall survival (OS) and progression-free survival (PFS). The OS was calculated from the first day of diagnosis to the date of death from any cause or last follow-up. The PFS was calculated from the last day of RT to the day of diagnosis of loco-regional and/or distant relapse in completely responded patients and progression of disease in partially responded patients. The probability of survival was calculated using the
Kaplan-Meier method. The log-rank test was used to evaluate the prognostic factors of the survival rate. Multivariate analysis was performed using Cox's proportional hazard model. The statistical test was a two-sided test and was performed with SPSS ver. 12.0 (SPSS Inc., Chicago, IL, USA).

\section{Results}

\section{Overall clinical outcome}

The median follow-up time was 30 months (range, 11 to 83 months) for all the patients and 39 months (range, 19 to 83 months) for the surviving patients. After Induction chemotherapy, $53 \%$ of patients achieved partial response and the rest did stable disease. After RT or CCRT, complete response in $74 \%$, partial response in $16 \%$, stable disease in $8 \%$ and progression of disease in one patient. Five-year OS rate was $65 \%$ (Fig. 1). Stage, gender, and age were not significant prognostic factors of OS or PFS on the analysis.

\section{Results of immunohistochemical staining}

The IHC result is summarized in Table 3. For EGFR, we graded in both intensity and extent. In $\mathrm{nm} 23-\mathrm{H} 1$, the intensity of the staining was very weak in positive cases. We repeated IHC staining for nm23-H1 three times without improvement of the staining intensity. However we preceded the study on $\mathrm{nm} 23-\mathrm{H} 1$ because it was possible to distinguish positive from negative cases.

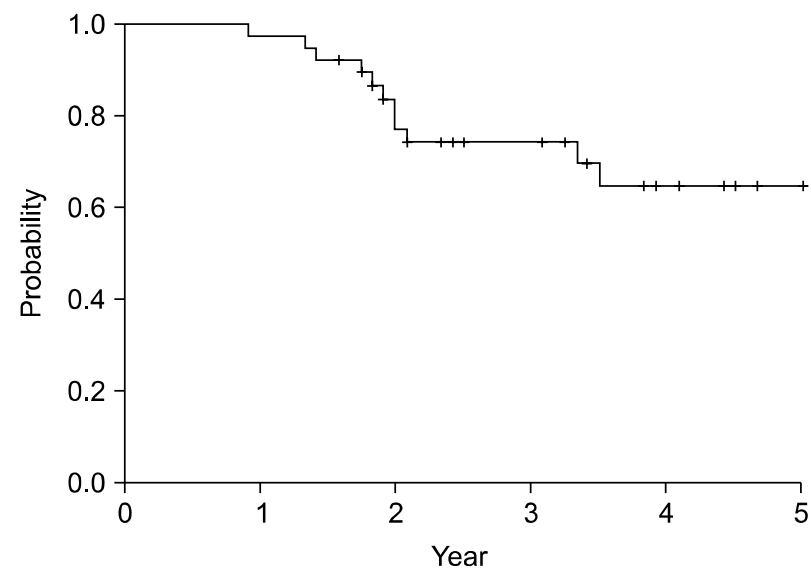

Fig. 1. Overall survival of all patients. The 5-year overall survival rate was $65 \%$. 


\section{Correlation of biomolecular markers with over- all survival}

The 5-year OS rate of the patients with high Met extent was significantly worse than that of the patients with low Met extent on the univariate analysis ( $48 \%$ vs. $84 \%, p=0.02$ ) (Fig. 2). Met extent was also a significant prognostic factor on the multivariate analysis $(\mathrm{p}=0.01)$. No correlation was observed between Met extent and $\mathrm{T}$ stage, $\mathrm{N}$ stage, stage group, gender, age or the response of chemotherapy or RT. Met extent showed moderate correlation with $\mathrm{COX}-2$ expression (Pearson coefficient $0.496, \mathrm{p}<0.01$ ), but COX-2 expression did not affect OS. Either nm23-H1 or EGFR expression was not a

Table 3. Frequency of Biomolecular Markers

\begin{tabular}{|c|c|c|}
\hline \multicolumn{2}{|c|}{ Biomolecular factor } & \multirow{2}{*}{$\frac{\text { No. of patient }(\%)}{3(8)}$} \\
\hline Met & $<10 \%$ & \\
\hline & $10 \sim 50 \%$ & $13(34)$ \\
\hline & $>50 \%$ & $22(58)$ \\
\hline \multirow[t]{4}{*}{ COX2 } & Negative & $2(5)$ \\
\hline & $<25 \%$ & 5 (13) \\
\hline & $25 \sim 50 \%$ & $13(34)$ \\
\hline & $>50 \%$ & $18(47)$ \\
\hline \multirow[t]{2}{*}{ nm23-H1 } & Negative & $31(82)$ \\
\hline & Positive & 7 (18) \\
\hline \multirow[t]{3}{*}{ EGFR $^{*}$ intensity } & Weak & 19 (50) \\
\hline & Moderated & $11(29)$ \\
\hline & Strong & $8(21)$ \\
\hline \multirow[t]{3}{*}{ EGFR extent } & $<5 \%$ & $8(21)$ \\
\hline & $5 \sim 25 \%$ & $10(26)$ \\
\hline & $>25 \%$ & $20(53)$ \\
\hline
\end{tabular}

*epidermal growth factor receptor. prognostic factor for OS in this study. All of these four biomolecular markers did not affect progression free survival. The prognostic values of these biomarkers are demonstrated in Table 4.

\section{Patterns of failure}

Local progression was observed in 5 patients and distant metastasis in 7 patients (Fig. 3). Six of 7 patients who developed distant metastasis showed high Met expression.

\section{Discussion and Conclusion}

The 5-year OS rate was reported as $30 \%$ to $60 \%$ in patients

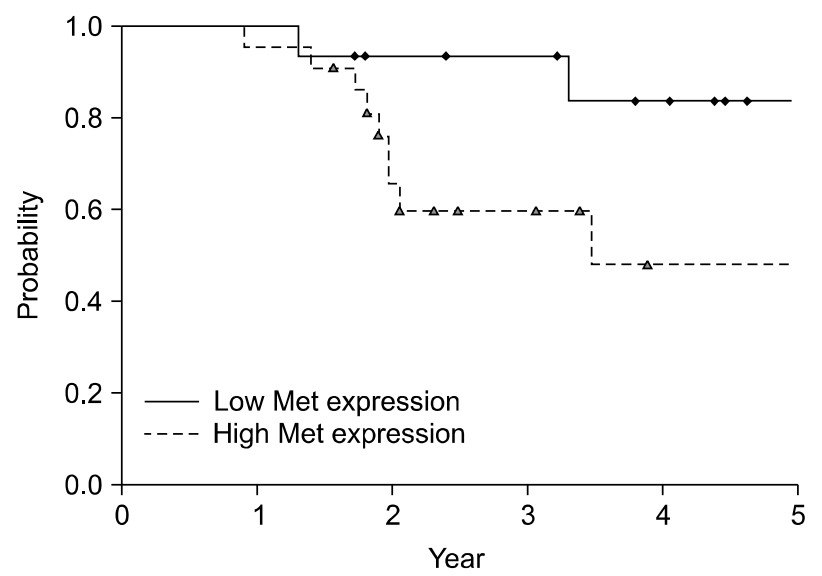

Fig. 2. Overall survival according to Met expression. The 5 -year overall survival rate was $48 \%$ in the patients with high Met extent and $84 \%$ in those with low Met expression $(\mathrm{p}=0.02)$.

Table 4. Prognostic Value of Biomolecular Markers

\begin{tabular}{|c|c|c|c|c|c|}
\hline Markers & & No. (\%) & 5 -yr overall survival (\%) & Hazard ratio & $95 \%$ confidence interval \\
\hline \multirow[t]{3}{*}{ Met } & $\leq 50 \%$ & $16(42)$ & 84 & & \\
\hline & $>50 \%$ & $22(58)$ & 48 & & \\
\hline & & & $p=0.02$ & 5.56 & $1.19 \sim 26.06$ \\
\hline \multirow[t]{3}{*}{ COX2 } & $<25 \%$ & $7(18)$ & 66 & & \\
\hline & $\geq 25 \%$ & $31(82)$ & 64 & & \\
\hline & & & $p=0.61$ & 1.64 & $0.36 \sim 7.43$ \\
\hline \multirow[t]{3}{*}{$\mathrm{nm} 23-\mathrm{H} 1$} & Negative & $31(82)$ & 63 & & \\
\hline & Positive & 7 (18) & 69 & & \\
\hline & & & $\mathrm{p}=0.94$ & 1.06 & $0.23 \sim 4.94$ \\
\hline \multirow[t]{2}{*}{ EGRF intensity } & Weak & $19(50)$ & 75 & & \\
\hline & Moderate or strong & $19(50)$ & $\begin{array}{l}55 \\
p=0.23\end{array}$ & 2.04 & $0.62 \sim 6.70$ \\
\hline \multirow[t]{3}{*}{ EGRF extent } & $\leq 25 \%$ & $18(47)$ & 70 & & \\
\hline & $>25 \%$ & $20(53)$ & 59 & & \\
\hline & & & $\mathrm{p}=0.89$ & 1.39 & $0.45 \sim 4.27$ \\
\hline
\end{tabular}




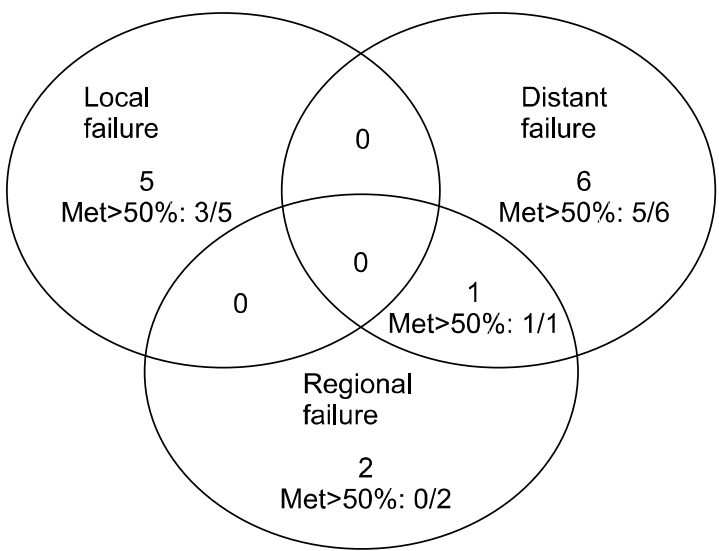

Fig. 3. Patterns of failure and proportion of high Met expression. Six of 7 patients who developed distant metastasis showed high Met expression.

with locally advanced NPC treated with RT alone.") Recently concurrent radiotherapy and chemotherapy has been proposed for locally advanced NPC to improve 5-year OS rate up to $62 \%$ and 3 -year OS rate up to $80 \% .^{5 \sim 7)}$ There are several clinical prognostic factors such as stage, gender, and age for NPC. However, among even the same staged patients, the treatment outcomes are variable. In addition to these clinical prognostic factors, biomolecular markers could help us to predict the treatment outcome.

In the present study, we performed an immunohistochemical study with pre-treatment biopsy specimens to identify biomolecular markers which can be used as a predictive assay for NPC, in order to modify therapeutic approaches. The correlation between Met, COX-2, nm23-H1, EGFR expression and survival time was explored. We found that Met protein expression was inversely correlated with survival time. Met tyrosine kinase, the receptor for $\mathrm{HGF} / \mathrm{SF}$, is important in various cellular functions including proliferation, mitogenesis, formation of branching tubules, angiogenesis, and tumor cell invasion and metastasis. This result is consistent with the previous study, ${ }^{8)}$ which showed high Met protein expression levels correlated with poorer survival in late-stage NPC and served as an independent prognostic indicator. In their study the mean survival time was 118 months in low Met expression group vs. 52 months in high Met expression group (p $<0.01)$. One of the explanations of this inverse correlation is that when the cancer cells have high Met mutation, they gain the ability of proliferation, motility, invasion and survival against chemotherapeutic agents. ${ }^{9)}$

Met extent showed moderate correlation with COX-2 expression, but COX-2 expression did not affect OS in this study. Prostaglandins play a critical role in tumor development and growth by regulating numerous biologic processes, including tumor angiogenesis, with clear prognostic and therapeutic implications. The prostaglandin $\mathrm{H}$ synthase 2, which is $\mathrm{COX}$ 2 , is up-regulated in various malignancies, such as colon, lung, breast cancer and head and neck squamous cell carcinoma. Although COX-2 over expression appeared to predict a shorter survival in other study, ${ }^{10,11)}$ we failed to show the prognostic significance of $\mathrm{COX}-2$ in this study.

It is known that nm23-H1 may function as a suppressor gene for tumor metastasis. Expression of nm23-H1 protein indicated favorable prognosis, suggesting that the absence of $\mathrm{nm} 23-\mathrm{H} 1$ protein expression was significantly associated with lymph-node metastasis, recurrence and distant metastasis in NPC. The distant metastasis and loco-regional recurrence rates in the nm23-H1-negative group were $55.8 \%$ and $31.7 \%$, respectively but only $17.2 \%$ and $11.5 \%$ respectively in the nm23-H1-positive group $(\mathrm{p}<0.01)$ in the previous study. ${ }^{12)}$ However we could not find any prognostic value of nm23-H1.

EGFR expression intensity in undifferentiated NPC is associated with a poor clinical outcome. Strong EGFR expression, when compared with weak or moderate, was associated with poorer overall survival rate $(p=0.04)$ in a subgroup of patients with International Union Against Cancer (UICC) stage III-IV disease. ${ }^{13)}$ Correlative analysis showed that EGFR extent was also a strong, independent prognostic factor that determined loco-regional control, relapse-free survival, and disease specific survival in NPC treated with induction chemotherapy and RT. ${ }^{14,15)}$ However, the prognostic value of EGFR is still controversial in NPC. One study showed that EGFR expression is a negative prognostic factor in NPC as well as other head and neck cancers, ${ }^{13)}$ but another study showed no statistically significant correlation between EGFR expression and treatment outcome in NPC. ${ }^{16,17)}$ Neither EGFR intensity nor extent was a prognostic factor for OS in this study.

No correlation was observed between Met extent and $\mathrm{T}$ stage, $\mathrm{N}$ stage, stage group, gender, age or the response of chemotherapy or RT. This might be due to the small number of each subgroup. This study has limitations of retrospective study. First, patients and treatment were heterogeneous. 
Second, not all of the paraffin blocks of the patients were available for the immunohistochemical staining. These limitations might cause the discrepancy between this study and previous studies.

In conclusion, high Met expression might be an independent prognostic factor that predicts poor OS in NPC. Other biomolecular markers are under evaluation to reveal their impact on the prognosis. Large scaled prospective study is required to confirm the prognostic values of the biomolecular markers.

\section{References}

1. Ministry for Heath, Welfare and Family Affairs. Annual Report of Cancer Incidence (2005) and Survival (1993-2005) in Korea. Seoul: Ministry for Heath, Welfare and Family Affairs, 2008

2. Fandi A, Altun M, Azli N, Armand JP, Cvitkovic E. Nasopharyngeal cancer: epidemiology, staging, and treatment. Semin Oncol 1994;21:382-397

3. Kim S, Grandis JR, Rinaldo A, Takes RP, Ferlito A. Emerging perspectives in epidermal growth factor receptor targeting in head and neck cancer. Head Neck 2008;30: 667-674

4. Heng DM, Wee J, Fong KW, et al. Prognostic factors in 677 patients in Singapore with nondisseminated nasopharyngeal carcinoma. Cancer 1999;86:1912-1920

5. Al-Sarraf M, LeBlanc M, Giri PG, et al. Chemoradiotherapy versus radiotherapy in patients with advanced nasopharyngeal cancer: phase III randomized Intergroup study 0099. J Clin Oncol 1998;16:1310-1317

6. Wee J, Tan EH, Tai BC, et al. Randomized trial of radiotherapy versus concurrent chemoradiotherapy followed by adjuvant chemotherapy in patients with American Joint Committee on Cancer/International Union against cancer stage III and IV nasopharyngeal cancer of the endemic variety. J Clin Oncol 2005;23:6730-6738

7. Baujat B, Audry H, Bourhis J, et al. Chemotherapy in locally advanced nasopharyngeal carcinoma: an individual patient data meta-analysis of eight randomized trials and 1753 patients. Int J Radiat Oncol Biol Phys 2006;64:47-56

8. Qian CN, Guo X, Cao B, et al. Met protein expression level correlates with survival in patients with late-stage nasopharyngeal carcinoma. Cancer Res 2002;62:589-596

9. Benvenuti S, Comoglio PM. The MET receptor tyrosine kinase in invasion and metastasis. J Cell Physiol 2007;213: 316-325

10. Chen WC, McBride WH, Chen SM, et al. Prediction of poor survival by cyclooxygenase-2 in patients with T4 nasopharyngeal cancer treated by radiation therapy: clinical and in vitro studies. Head Neck 2005;27:503-512

11. Kim K, Wu HG, Park SW, Kim CJ, Park Cl. Expression of cyclooxygenase (COX)-2 as a prognostic factor in Nasopharyngeal Cancer. Cancer Res Treat 2004;36:187-191

12. Guo X, Min HQ, Zeng MS, et al. nm23-H1 expression in nasopharyngeal carcinoma: correlation with clinical outcome. Int J Cancer 1998;79:596-600

13. Ma BB, Poon TC, To KF, et al. Prognostic significance of tumor angiogenesis, Ki 67, p53 oncoprotein, epidermal growth factor receptor and HER2 receptor protein expression in undifferentiated nasopharyngeal carcinoma: a prospective study. Head Neck 2003;25:864-872

14. Chua DT, Nicholls JM, Sham JS, Au GK. Prognostic value of epidermal growth factor receptor expression in patients with advanced stage nasopharyngeal carcinoma treated with induction chemotherapy and radiotherapy. Int $\mathrm{J}$ Radiat Oncol Biol Phys 2004;59:11-20

15. Taheri-Kadkhoda Z, Magnusson B, Svensson $M$, Mercke C, Bjork-Eriksson T. Expression modes and clinical manifestations of latent membrane protein 1, Ki-67, cyclin-B1, and epidermal growth factor receptor in nonendemic nasopharyngeal carcinoma. Head Neck 2009;31:482-492

16. Leong JL, Loh KS, Putti TC, Goh BC, Tan LK. Epidermal growth factor receptor in undifferentiated carcinoma of the nasopharynx. Laryngoscope 2004;114:153-157

17. Chae SM, Lee YS, Kim YS, et al. EGFR, p53, Cox-2 and $\mathrm{Bcl}-2$ expression in nasopharyngeal carcinoma and their potential clinical implication. J Korean Soc Ther Radiol Oncol 2007;25:43-53 


\title{
방사선 치료를 받은 코인두암의 생체분자적 예후 인자를 찾기 위한 면역조직화학염색 연구
}

\author{
서울대학교 의과대학 방사선종양학교실*, 병리학교실 ${ }^{\dagger}$, 암연구소 ${ }^{\ddagger}$, \\ 서울대학교 의학연구원 방사선의학연구소 \\ 김연주 $^{*} \cdot$ 이승희 ${ }^{*, \S} \cdot$ 우홍균 $^{*, \uparrow} \cdot$ 고현정 $^{\dagger} \cdot$ 전윤경 $^{\dagger}$
}

목 적: 방사선 치료를 받은 코인두암 환자의 치료 전 조직을 면역조직화학염색하여 생체분자적 예후인자를 찾고자 하였다.

대상 및 방법: 1998년부터 2006년까지 방사선 치료를 받은 코인두암환자는 68 명이었다. 이중 38명의 환자에서 면 역조직화학염색을 위한 파라핀 블록을 찾을 수 있었다. 전체 환자 중 31 명은 미분화암종이었고, 7 명은 편평세포암 종이었다. 전체 환자의 84\%가 2002 American Joint Committee on Cancer Stage III or IV 환자였다. 전체 환자의 파라핀 블록을 이용하여 Met, COX-2, epidermal growth factor receptor (EGFR), nm23-H1에 대해 면역조직화학염 색을 시행하였다.

결 과: 전체 환자의 중앙 추적 기간은 30 개월이었고 생존 환자의 중앙 추적 기간은 39 개월이었다. 높은 $(\geq 50 \%)$ Met 발현을 보인 환자들의 5 년 생존율은 $48 \%$, 낮은 Met 발현을 보인 환자들의 5 년 생존율은 $84 \%$ 로 이는 통계적 으로 유의한 차이를 보였다 $(\mathrm{p}=0.02)$. Met 발현 정도는 다변량 분석에서도 유의한 인자로 분석되었다 $(\mathrm{p}=0.01)$. Met 발현은 종양의 병기, 성별, 나이, 항암제나 방사선 치료에 대한 반응 정도와 상관관계를 보이지 않았다. Met 발현 정도는 COX-2 발현과 중등도의 상관관계를 보였으나(Pearson coefficient 0.496, p<0.01), COX-2 발현은 전체생 존율에 영향을 미치지 않았다. 본 연구에서는 nm23-H1이나 EGFR의 발현은 예후인자가 아닌 것으로 분석되었다. 결 론: 방사선치료를 받은 코인두암에서, 높은 $(\geq 50 \%)$ Met 발현은 전체생존율에 영향을 미치는 독립적인 예후인 자일 가능성이 있다.

핵심용어: 코인두암, 방사선치료, 예후인자, 면역조직화학염색, Met 